Прегледни чланак

Zoltán Z. Józsa, Ph.D., Associate Professor

University of Szeged

Faculty of Law

jozsaz545@gmail.com

\title{
THE MAIN STAGES IN THE DEVELOPMENT OF THE OFFICIAL ADMINISTRATION IN HUNGARY
}

\begin{abstract}
„,The feelings people have when they enter an office are significant, but the feelings they have upon leaving are even more significant. ${ }^{.}$
\end{abstract}

\begin{abstract}
After a brief outline of the past, the study focuses on the three main elements of public administration: the organization, the tasks and competences, and the characteristics of the staff.

Different but complementary research methods (historical, comparative and dogmatic) show the changes in the management and operation of state administration over historical periods. The formal, subordinated administration has gradually given way to a customer-friendly, service-oriented administration. The corresponding organizational framework is the government window system, while the institutions the Act of General Administrative Procedures provide the opportunity to implement fast, cheap and efficient state services. The commitment, skills, and professionalism of the public administration staff remain the most important factor for the realisation of a modern, service-oriented state.

Changes like state administration are not straight-line, but the tendency is the strengthening of the help and service image.

Keywords: State administration, administrative office, state administrative services, government window, Act on General Administrative Procedures, customer-friendly administration.
\end{abstract}

\section{INTRODUCTION}

For historic conceits and reflexes, the expression 'authority' raises ambivalent feelings and reactions even in those who are familiar with public matters. According

\footnotetext{
${ }^{1}$ Ferenc Dudas, "Effective Information, Improving through e-administration, the level of information provided to clients, with special regard to call centres" Notary and Public Administration 3/2004. 12.
} 
to public opinion, the authority is the state itself, the institution of the state by which the will of the state and the laws that express the will of the state prevail.

The authority administers cases based on laws, regulations, instructions, etc. using a language that is incomprehensible for those using plain language only. The proceedings are lengthy and circuitous due to the infinite labyrinth of the authority and the outcome of cases can be unpredictable at times. The office is mystical, distant and strange and thus the relationship between the office and the public may rather be associated with careful reticence than seemed as interactions between equals. The relationship between the authority and people (clients) are specific as the professional dominance of the authority recreates and strengthen such hierarchy.

It was a long way until the authority which was once distant from clients, bureaucratic, heavy and slow became an organisation which is open, client-friendly and close to the citizens, And without any kind of official dominance and arrogance, not only executes law but also provides information, enables, assist to and support clients when adopting the decision.

This study, following the historical summary, focuses on the three dominant elements of administrative proceedings as well the relationships amongst those elements, such as the organisation, the powers attached to the organisation, the fundamental rules of administrative procedures and the changes therein, and the personal qualities that affect the level of administrative proceedings.

The complexity of the subject requires monographic processing, so the study focuses on the main tendencies rather than on the often-contradictory details, due to the limitation of the scope.

\section{AUTHORITY, STATE ADMINISTRATIVE CASE, STATE ADMINISTRATIVE SERVICE}

There are two major subsystems of public administration in Hungary: state and local administration. Public administration is primarily performed by state institutions, but state tasks are also performed by local government bodies.

In today's modern state, state administrative task and matters are already carried out not only by the state administration and municipal authorities but also by the widening range of non- public bodies ${ }^{2}$ performing public administration tasks in the official activities.

The Act on General Administrative Procedures also refers to the expanding range of public authorities which are part of public administration, according to

\footnotetext{
${ }^{2}$ Istvan Balázs, "Alternatives of organising state services by administrative authorities" New Hungarian Public Administration 3/2015, 2-13.
} 
which: 'for the purpose of this Act authority means a body, organization or person empowered by an act, government decree or - in administrative actions of local authorities - municipal decree to exercise official authority or designated by law to exercise official authority. Cases falling within the competence of the authority may not be transferred. ${ }^{3}$

The authorities conducting administration act in a matter of state administration, ${ }^{4}$ the concept of which is laid down by law as follows: 'In administrative actions falling within the scope of this Act (hereinafter referred to as 'case') and in regulatory inspections the authority shall apply the provisions of this Act.' For the purposes of this Act, case means where the authority brings a decision to define a client's right or obligation, to settle a client's dispute, to establish a client's infringement, to verify a fact, status or data or to keep records, and where it moves to enforce such decision. ${ }^{5}$

Due to its peculiarities, the state administration was typically a relationship of subordination between the authority and the client, concerning the observance of material and procedural norms, and less to deal with speed, economy and customer affairs.

The need for a quick, simple and economical procedure not only in the municipal but also in the public administration cases led to the fact that in the official procedure, instead of the common concept of administration, the term 'service' was gradually expanded, referring to the need to change classical practice. This means not only a change of terminology but also a change in content, as the codes governing official procedures and some of their legal institutions sought to meet new requirements for administration.

\section{THE HISTORICAL PAST THAT AFFECTS THE PRESENT}

The development of Hungarian bureaucracy started in the age of enlightened absolutism. ${ }^{6}$ The central offices saw reorganisation, the number of qualified officials increased and public service becomes a profession, except for the county.

There were measures taken to standardise administrative procedures, in particular state administration.Until the early 18 the century, files were not registered. Changes were brought by the decree of Maria Theresa and Joseph II.7 In addition,

\footnotetext{
${ }^{3}$ Act CL of 2016 - on General Public Administration Procedures, Section 9.

${ }^{4}$ Lajos Lörincz, Basic Institution of Public Administration HVG ORAC, Budapest 2010, 172-175.

${ }^{5}$ Act CL of 2016- on General Administration Procedures, Section 7.

${ }^{6}$ Andor Csizmadia, Bureaucracy and administrative reforms in Hungary, Gondolat Budapest, 1979, 8-9.

${ }^{7}$ Ibid., 8-9.
} 
after 1849, financial, accounting and tax administration system was introduced under the Austrian system.

Until the $19^{\text {th }}$ century, many reform ideas such as Hajóczy, Martinovics or Berzeviczy failed due to the resistance of the county and the Hungarian nobility. However, the feudal administration was broadening and specialised, and these steps introduced bureaucratic features in public administration. Debates on matters about public administration continued in the second part of the century in reform diets, county assemblies and towns. Centralists urged a fundamental reform of the county's administration but had partial success only.

The foundations of a civil administration were laid down after the war of independence of 1848-1849; however, there was no time to implement the adopted reforms. The oppressing Austrian Empire introduced several bureaucratic innovations in the country, in particular by applying the good practices of tax and financial administration.

The dominance of county administration possessed by the noble-gentry class over towns in administration remained intact even after the Compromise in 1867. The citizenry had influence only in the specialised administration of towns. In the midst of strong economic and social development, successive governments aim to centralize public administration on the one hand and to find a compromise between feudal and civil forces on the other. The revision of the Act on towns, the capital and committee were on the agenda at the beginning of the $20^{\text {th }}$ century, with the need that this Act is adapted to the requirements of the era.

However, a hierarchical system of deconcentrated organs dependent on the central government represents administration rationality and professionals in certain specialised fields was gradually developed and operated next to the non-professional local government system. That was based on prerogatives and privileges and meant permanency. The spread of professional state administration based on qualification, which provides a predictable career, was a decisive step in the development of civil administration.

In the era between the two world wars, deconcentrated organs, as the institutions of the state, gained an important role in more and more specialised fields, implementing the aspects of legality, professionalism and predictability in administrative proceedings.

Between the two world wars, governments coming and going all had the issue of modernising public administration ${ }^{8}$ on their agenda (Act on towns, Act on settlements, Act on administrative procedures). However, the social and poli-

${ }^{8}$ The lecture of state secretary Imre Sandor was part of the Public Administration Further Training Course held in 1936. The lecturer emphasized that mutuality of the effects of public administration and the public, as well as the thesis that public administration, in its entirety, public 
tical milieu was not favourable for changes, and even the ideas of so prominent personalities, such as Zoltán Magyary's proposals for rationalisation, failed. ${ }^{9}$

From among the numerous proposals and plans ${ }^{10}$ Weis István's proposal on vesting authority powers upon notaries, who are qualified officials, should inter alia be mentioned here. His thought according to which lower authorities should handle individual cases, authorities of intermediate level should carry out supervision, and authorities of the highest level should govern, instead of dealing with individual cases, is worth mentioning.

Although reforms of larger scale did not happen, certain specialised fields, such as military, social, public health, agricultural and civil registration administration saw successful endeavours.

Generally speaking, the territorial and local systems of state administration, in which administration of cases was bounded by the law and was professional, in sharp contrast to the underdeveloped methods and procedures of the county, began after 1867 and continued after the world wars.

\section{SOCIALIST STATE ADMINISTRATION: AUTHORITY AND POWER}

After 1945, national committees were given the authority to build a system of democratic self- government and to set up organs of state administration. There were numerous proposals developed on reforming the system of state administration and the local government system. For instance, the town-county concept of Erdei aimed at attaching specialised organs of administration to the organs of general administration. The district government commissioners would have headed the different branches of specialised administration, simultaneously with coordinating the measures of central authorities.

After 1950, representative and official functions were separated in the committee system, at local, district and of county-level as well. Specialised organs of administration were vested with administrative duties and were subject to the professional supervision of the executive committees and secretaries. The specialised organs of administration constituted a unified and divided structure based on the size of the town and the scope of duties. ${ }^{11}$

service; The offices are for the public and not another way around that is the public for the offices. The office must serve the public.

${ }^{9}$ Zoltan Magyary, Hungarian Public Administration, Royal Hungarian University Press, Budapest, 1942.

${ }^{10}$ Károly Martonffy, The renewal of Hungarian Public administration, Royal Hungarian University Press, Budapest, 1940.

${ }^{11}$ Gyula Fonyó, Handbook of local councillor, MTTH, Budapest, 1985, 25-61. 
The socialist state administration was based on the principle of democratic centralism, ${ }^{12}$ according to which the purpose of public administration to serve the society either directly or indirectly. The democratic of administration means - according to the contemporary interpretation - that public administration for the benefit of the society as a whole can be achieved if they manage and control the public administration, which is also its subject. This facilitates that the system of administration and administrators serve the interests of the whole society and prevents the administration from becoming a strange power that is supreme to the community.

The inherent inconsistencies of this reasoning are obvious: on the one hand, the idea of those subject to administration (clients) participating in the administration of administrative cases without adequate technical knowledge is an empty fiction. On the other hand, those subject to administration can 'control' administration only if they are capable of determining and as well as supervising the activities of the directors.

The principle of democratic centralism did not apply to the detailed rules on the legal status, and organisation and operation of specialised organs of administration. Although these organs qualified as legal persons, their budgets belonged to the unified budget of committees. The higher-level bodies, as well as the size of the city involved determined their organisational divisions. This resulted in the creation of specialised, unified or divided, organs of administration.

Customer services ${ }^{13}$ operated in larger towns, the capital and settlements other than seats as well as branches located in remote parts of towns facilitated the administration of administrative cases. It was possible to have so-called 'administration days' when the employees of branches kept office hours on the days designated as such in the organisational and operational regulations.

\section{CHANGES OF THE ORGANISATIONAL STRUCTURE OF STATE ADMINISTRATION FROM 1990 UNTIL TODAY}

The change of the political and economic structures after 1990 not only resulted in the complete transformation of the public law system through the establishment of democratic institutions but it affected significantly the expectations ${ }^{14}$ regarding the role of public administration in society.

\footnotetext{
${ }^{12}$ S.Berényi et al. Hungarian state administrative law, General Chapter, Ministry of home affairs, Budapest, 1984, 138-153.

${ }^{13}$ Gyula Almássy, Development of public administration and technology, $\mathrm{PhD}$ thesis, $\mathrm{Bu}-$ dapest, 2012, 55.

${ }^{14}$ Christoph Demmke, "Governmental, organisational and Individual performance" Eipascope $1 / 2006,5-12$.
} 
Contrary to the monolithic state administration system of socialism, civil public administration consists of two important sub-systems: state administration and municipal administration, the latter enjoying wide independence. The legislator has striven to separate state administration cases and municipal cases, whilst, local governments carried out state administration powers on a large scale.

The existence of county governments with strong autonomy under public law but vested with weak duties and responsibilities. The administration vacuum at regional level resulted in those ministries established deconcentrated organs in large number for the fulfilment or otherwise unfulfilled public functions. ${ }^{15}$

As there was no real link between the bodies in each sector, relatively similar tasks and procedures were regulated differently. The deconcentrated organs provided services of different quality to the clients, and apart from some fields, the territorial differences remained intact. In the period between 1990 and 1994, in each county, there were more than 30 of such offices ${ }^{16}$ and the offices, under different controls and weak supervision showed a low level of performance.

After 1994, the offices of public administrations had more and more duties and responsibilities. The Government, in the context of a programme for modernising public administration, reviewed the system of deconcentrated organs and decreased its number. Deconcentrated units were territorial organs of state administration ${ }^{17}$ implementing different responsibilities such as licensing, environmental protection, supervision etc.

The goal was to establish a unified territorial administration by merging and integrating deconcentrated organs that belong to the same sectors. The government office of the capital city and the county government offices, as custodians of the efficiency of governance at a regional level, had an important role in the process. In 1996, public administration offices transformed into government offices, absorbing numerous organs of different sectors.

The 2006 amendment of the Act on local governments deleted the words capital city and county from the designation of public administration offices, and the territorial competence of different public administration offices thereafter covered different regions, instead of counties. Except for in county seats other than those being the seats of an office, there were branches, and sectorial specialised administration organs, as organisational units of the public administration offices, were operating. As of 1 January 2009, regional public administration offices were replaced by regional offices of state administration.

${ }^{15}$ Attila Barta, Territorial state administration in Hungary, Gondolat, Budapest, 2013, 133-136.

${ }^{16}$ Ilona Kovács Pálné, "Transformation of the local government system and territorial administration 2010-2013” MTA Law Working Paper, Budapest 2/2014.

${ }^{17}$ István Balázs, Changes in public administration in Hungary and Europe, from the change of regime to the present day, University Press, Debrecen, 2011, 59. 
There are no specific data or surveys on the influence of structural changes had on the administration of cases. The classic bureaucratic nature of deconcentrated organs remained dominant even after the nineties, regardless of government efforts for rationalising and modernising these organs (integration, revision of duties and responsibilities, realignments, limitation of the number of staff, etc.).

In addition to deconcentrated organs, local governments had also an important role in conducting administrative proceedings of state administration and municipal administrative proceedings.

The notary, as a recipient of state administration duties and responsibilities, proceeded as a first- instance authority in certain cases of specified areas. The responsibilities of a notary included matters for which local knowledge and being near to clients (registration, social affairs, protection of possession, etc.) were of crucial importance.

In administrative cases falling under notarial responsibilities, the conditions for direct and fast administration were met due to closeness in terms of geography. However, mainly in smaller settlements, professional and efficient proceedings were not available to citizens due to the lack of sufficient professional, technical and financial sources. This is the reason why legislator assigned the cases that requires significant technical background and professional training to the notaries of district seats and record's bureaus ${ }^{18}$ throughout the country.

After 2010, the complete transformation of territorial public administration become the most important element of the public administration organisational reforms. The Government decided on transforming the organisational structure of territorial state administration in Government Decision 1191/2010 (IX. 14.). The goal was to separate state administration and municipal duties and to unite the divided organisational structure of territorial public administration. ${ }^{19}$ The integration of organizations from different sectors was preceded by lengthy technical preparation and consultation. The principle of the transformation was to merge the bodies dealing with public administration matters and those related to the clients.

The government office of the capital city, the county government offices, and the district offices started working as of 1 January 2011 and 1 January 2013, respectively after the integration of territorial specialised organs of administration. The basic organisational principle when establishing the district offices was that they function as the capital and county government offices. ${ }^{20}$

\footnotetext{
${ }^{18}$ András Szekeres, "Changes in the notary's administrative powers"Notary and Public Administration 3/2012, 5-7.

19 Tamás Piltz, "Organization and operation of the capital offices and county government offices" AROP-1. 1.26-2013-0001. Manuscript, 24-25/ 2013.

${ }^{20}$ Vikória Zöld Nagy, "Districts and formation of districts offices" Notary and Public Administration 3/2012, 4-5.
} 
Recognising that pilot studies may facilitate the optimal allocations of duties and powers, the delineation of the areas of the district was preceded by the designation of the specific responsibilities to be conferred to the district. Therefore, a mixed solution ${ }^{21}$ was adopted regarding notaries' duties and responsibilities about state administration. Administration at the local level, matters requiring local knowledge and addressing without delay as well as certain notarial functions related to the power of bodies of representatives of local governments to adopt decrees remained at the local level. ${ }^{22}$

Government windows (One-stop offices) are local offices where local citizens can arrange several cases mostly immediately. Government windows as organisation units of district offices, operating as service providers as well, bearing the needs and interests of clients in mind. The first opened at 29 venues: in the capital city, county seats and towns with county rank in January 2011.

The modernisation of territorial state administration entered a new phase as of 2015.23 The unified organisation structure of government offices and district offices has been achieved through external and internal integration in order to speed up and simplify the procedure.

The Government's Public Administration and Public Service Development Strategy for the period between 2014 and 2020 (www.kormany.hu) focus on strengthening further the institutional system of territorial state administration, modernising the district system and continuously developing the system of government windows.

The physical and information technology structures are quite essential for the organisation to operate with efficiency. Spreading information technologies are one of the most important and modern means of increasing the efficiency of public administration. Broadening the scope of e-public administration services and improving their quality is of key importance both for public administration clients and for the facilitation of the work of those fulfilling duties in public administration.

\section{FROM THE GENERAL RULES OF ADMINISTRATIVE PROCEDURES TO THE ACT OF GENERAL RULES OF ADMINISTRATIVE PROCEEDINGS AND SERVICES}

It is important to note the subsequent post-1990 changes of the aforementioned forum system of state administration was not accompanied by the amendment

\footnotetext{
${ }^{21}$ Mónika Kasza, Lóránd Mezey, Tünde Mitták, "Three blows to the clerks" Notary and Public Administration 1-2/2015, 16-64.

${ }^{22}$ Pál Kiss, "Government and/or municipal empowerment in the village? How to continue local administration? Questions of the division of powers between the district and local authorities" Notary and Public Administration special issue/2015. 5-7.

${ }^{23}$ Attila Barta, "Integration processes for territorial administration in 2015" New Hungarian Public Administration 3/2015, 14-20.
} 
of the Act on the rules of administrative procedure. Nonetheless, this does not mean that the legislator did not seek to adopt rules that are compatible with the changes in everyday circumstances. For example, Act IV of 1957 (hereinafter Áe.) was amended by Act 1 of 1981. Nevertheless, the basic procedure was still governed by the Áe., in most part, except if sectorial Acts granted derogation.

The procedural Act was modern and progressive when adopted and satisfied the requirements of legal certainty and a democratic public administration. Nevertheless, with the democratic transformation the role of the state, the institutional system of public administration and the relationship between central and local bodies also changed. These all affected the attribution of powers and official forum system as well.

The strengthening of international relations, cooperation with EU bodies made it necessary to have new kind of division of labour, new practices and methods in the proceedings of public administration organs.

Public administration in a state based on the rule of law provides for the client to enforce their procedural rights and to have the adopted decisions reviewed by the court. Therefore, public administration must facilitate the enforcement of client rights, and the application of instrument of powers must be preceded by voluntary compliance.

The gradual spread and use of modern information technology tools has provided a new perspective for both public authorities and customers, as well as in the relationship between public bodies and clients. Obstacles to fast, cost-efficient and customer friendly administration have been removed.

Even before the commission entrusted to draft General Rules of Administrative Proceedings and Services (hereinafter Ket.) started working, there were numerous surveys regarding those procedures which generally determines the quality of public administration services. In this context, compliance with the administration deadlines, circumstances of client services and the aspects of supporting client orientation was examined.

One of the priorities of the reform programmes of public administration was to create a new kind of administration system that provides services and to strengthen this approach, at both central and local levels. The administration type of services provided by public administration or local government organs is required to be performed in the widest extent possible. Citizens have the right to services of good quality ${ }^{24}$ founded from taxes, as much as they have the right to services of good quality in any area of the private sector against payment. At the beginning of the $21^{\text {st }}$ century, public discourse is rather pragmatic than ideological. What people want not less state, but rather better services, higher effectiveness and compliance with the principle of equality, dignity, law and democracy.

${ }^{24}$ Ferenc Dudas, “Administrative customer support charter" Notary and Public Administration 4/ 2004, 6-7. 
Citizens meeting public administration want their matters falling under the competences of the mayor's office or a state administration organ, to be dealt with permanently, within the shortest period. Preferably, with a single visit to the office or even without visiting the office at all, beyond working hours and free time, under cultural circumstances.

It is of equal importance that mayor's offices and other state administration organs provide complete and accurate information on administrative cases and procedures as well. The expectation is similar to other specialist bodies and institutions involved in client affairs.

An illustrative data from 2003 (Government Decision No. 1113/2003. (XI. 11.) shows, that citizens did not have the possibility of having their matters solved after working hours in $73 \%$ of towns and $33 \%$ of districts with country rank. This means that public administration rather focuses on establishing simple and costefficient operations than on clients' needs. ${ }^{25}$ This also means that, in consideration of the population statistical data published by the Hungarian Central Statistical Office on 1 January 2002, more than 3,300,000 citizens could not deal with administrative matters in these settlements after working hours. Ending or, if it not possible at least reducing the inequalities' at the territorial and local level was always a primary responsibility of public administration.

The development of the following areas has been a priority:

- inclusion of citizens and civil society organisations in developing public administration services,

- improvement of technical conditions for the operation and the provision of services to clients,

- necessary conditions for the disabled to deal with administrative matters and for child-friendly operation,

- modern devices providing the client with information ${ }^{26}$

The survival of the traditional approach is clearly shown by the fact that public administration organs primarily pay attention to the implementation of legislation, and only then do the public interest and the interest of customer care.

The unconditional respect of public administration for legality is understandable, but it is equally important at least that officials, instead of applying the laws abstractly and mechanically only, see the client behind the rules. This approach may help the public administration to work really as a service provider.

The surveys have proven, beyond doubt, that official solutions that improve the quality of public services help the establishment of client-friendly systems. Besides, to ensure equal opportunities for all citizens are needed to move forward.

\footnotetext{
${ }^{25}$ Ferenc Dudás, "Improvement of the administrative service system in the light of a survey system" Notary and Public Administration 5/2004, 11-15.

${ }^{26}$ Frenc Dudás, "On improving the performance of the public administration" Notary and Public Administration 3/2006, 10-11.
} 
For this purpose, the following actions have to be taken:

- reducing the administration deadline of certain official cases,

- drafting and applying client-friendly forms and samples,

- improving the comprehensibility of the language of official procedures,

- facilitating the digital submission of official applications submitted on a massive scale, and

- establishing an official method of dealing with deregulation ideas, proposal and civil initiations.

\section{THE EFFECT OF THE ACT ON GENERAL RULES OF ADMINISTRATIVE PROCEEDINGS AND SERVICES}

The legislator, upon recognising the fundamental transformation of social conditions, strengthening international relations, ${ }^{27}$ the changes of economic life and ownership structure ${ }^{28}$ the intensive development of information technologies ${ }^{29}$ as well as the impact thereof on public administration, prepared the bill on administrative proceedings and services in 2004.

The most important novelty introduced by Act CXL of 2004 on General Rules of Public Administrative Proceedings and Services in comparison of Áe., was that official procedures were client-driven and not office is driven, in the spirit of a service providing state. ${ }^{30}$ When dealing with the state administration and municipal administrative cases, clients are no longer burdened with collecting data, which are otherwise available at the offices. The data must be collected by the offices. In addition to the above, the Ket. provides for the opportunity of introducing electronic administration.

The most important innovations of Ket. ${ }^{31}$ from clients' were:

The Act introduced, as a new principle, the requirement of polite communications with clients, and kept the requirement of fast and simple proceedings. The contents of the protection of rights acquired and enjoyed by the client in good faith broadened. The principle of equality before the law has remained in the Act. The right of clients to fair administration was emphasised. The client's right to legal remedy is of highlig-

\footnotetext{
${ }^{27}$ Brussels evaluated the performance of Hungarian public administration annually due to Hungary's accession to the European Union.

${ }^{28}$ The demands of economic competitiveness required public administration to cease to be no obstacle to but to be assistance to business associations so that business associations can be quickly established and operated under reliable rules.

${ }^{29}$ The expanding spread and application of computers and other information technology databases opened up a completely new basis in administrative procedures.

${ }^{30}$ Zoltan Tóth, "Characteristics of state services in the administrative procedures act" Notary and Public Administration 2/2005, 5-7.

${ }^{31}$ Géza Kilényi, Commentary on the administrative procedure act, Complex Wolters, Budapest, 2009, 23-33.
} 
hted importance, and client rights are strengthened. The pursuit of cost efficiency and effectiveness are not principles. The office must ensure ex officio that clients not knowing the Hungarian language do not suffer any disadvantage in the proceedings.

The Act considers administrative procedures as services. ${ }^{32}$ The purpose of the Act is to achieve that client see authorities a helpful partner, not a body to be feared. Ket. emphasizes on the service providing nature of public administration. Before the adaption of Ket. the term of public services was primarily attached to local public matters, such as maintaining public roads and street lighting.

The Ket. defines, in more parts thereof, as to what is understood under the concept of administrative services and as to what ways it seeks to make client orientation more simple in the process of administrative procedures. For instance, the Act sets forth that authorities are not allowed to request from clients the provision of data that are on file in another authority' records under the law. In this way, clients are no longer obliged to obtain the necessary annexes for their application from other agencies. The decision-making authority does this. ${ }^{33}$

Electronic communication with authorities provides for the possibility of submitting applications to the authority via the Client Gateway, and after the submission of the application, the authority must proceed and to take the steps (e.g. obtaining specialised authority permits, etc.) that are necessary for adopting the final decision. It is important to note that the law in a separate chapter regulates the rules of electronic administration, given their importance.

Besides, there are many other institutions and new solutions in the basic procedure that facilitate the enforcement of client rights and strengthen the service providing nature of administrative proceedings. Data processing, the new rules of communication, the different rules of deadlines, the possibility of enjoying a supporter or administrative mediator as well as the possibility of entering into an administrative contract also worth mentioning.

In addition to the rules of legal remedy mentioned beforehand, the rules of enforcement have been amended as well. Not only legal certainty but also client rights are also protected by the increase of the number of fines, the use of default interest and the ex officio commencement of enforcement procedures.

\section{FROM KET. TO THE NEW CODE OF ADMINISTRATIVE PROCEDURES}

The National Assembly made the comprehensive revision of the rules of Ket. (Act CXI of 2008) with the primary purpose of rendering public administration

\footnotetext{
${ }^{32}$ Lajos Szabó, "New law to serve to costumers" Notary and Public Administration 1/2005, 6-7.

${ }^{33}$ Lajos Szabó, "The goal is to serve the customer better" Notary and Public Administration $2 / 2004,20$
} 
procedures more simple and faster. A number of changes were made through the Act LVI of 2009, which amended 168 pieces of legislation.

In addition to the numerous modification and the increased number of procedures excluded from the scope of the Ket., the adoption of a new procedural Act was justified upon two other circumstances: firstly, the adoption of the Code of administrative court procedure and secondly, the adoption of the Act on the reduction of administrative bureaucracy (Act CLXXXVI of 2015).

A fundamental requirement imposed on General Public Administration Procedures (hereinafter Ákr.) was to 'contain solutions which result in actual positive changes for clients in connection with official administration. ${ }^{34}$ One of the most important, if not the most important function of public administration procedures, is to provide a legal remedy, safeguard the interests and rights of clients, and prevent them from the arbitrary conducts of state organs and to simultaneously enforce the public interest. ${ }^{35}$

The new procedural code was required to be shorter the Ket. This requirement was a conceptual goal. Regarding the considerations to be enforced, the rules of Ákr. were meant to be simpler and more easily comprehensible ${ }^{36}$ for clients.

In the context of basic principles, protecting client rights, facilitating the exercise of client rights and the requirement of good faith and confidence were still emphasised.

The new law on public administration procedure establishes specific rules and requirements for the exercise of their procedural rights to increase the protection of persons restricted or impeded by their circumstances, applying positive discrimination to counterbalance their bias. This solution breaks with the previous approach, as the principles and the individual institutions regulated the Ket's system for minors and persons with disabilities separately. ${ }^{37}$

Regarding deadlines, one of the most crucial elements of administrative proceedings, the legislator introduced numerous new institutions, which serve the interest of clients, such as automatic decision-making, summary procedure, complete procedure and pending decisions. Shortened deadlines help to close simple cases fast with the final effect, help the implementation of client interests, and finally yet importantly, help the enforcement of the principle of cost-efficiency and effectiveness.

${ }^{34} \mathrm{~B}$. Hajas et al., Rules of administrative procedure I. Explanation of general administrative order HVG ORAC, Budapest, 2017, 27-28.

${ }^{35}$ Ibid. 34.

${ }^{36}$ Zoltan Juhász, General administrative order.Ákr. 2016-Ket. 2014. Wolters Kluwer, Budapest, 2017, 223-227.

${ }^{37}$ Anita Boros, "The third generation of Hungarian administrative procedural law is Ákr. I." New Hungarian Public Administration 1/2018, 1-8. 
A fundamental change in Ákr. is that the primary means of a legal remedy in appeal procedures is the administrative court action, although the scope of first instance decisions that can be challenged by an appeal before the court is still quite wide. However, an appeal can happen only if explicitly allowed by the Act.

Making administrative court action the primary means of legal remedy - in general - was based on the objective, professional and, in terms of geography, balanced court practice provided by judicial remedies. Judicial procedures are regulated in Act I of 2017 on the Code of Administrative Court Procedure (hereinafter Kp.)

The new legal norms of Ákr. and Kp. have not been applied for a long time. Therefore, it would be premature at this point to collect, analyse and assess these Acts in terms of the enforcement of client rights. However, the legislator's purpose of simplifying, speeding up and improving efficiency, all of which are directly associated with the service providing nature of official procedures, while serving other purposes as well.

\section{THE ROLE OF STAFF IN STATE ADMINISTRATIVE PROCEDURES}

Both theoretic and practical experts on public administration are familiar with the thought of Zoltán Magyary, according to which the goodness of public administration depends on the officials. ${ }^{38}$ This saying of Zoltán Magyary which have become a catchphrase by time means that if the members of organs are not well-prepared and motivated enough and do not strive to fulfil their duties at a high quality and efficiency, it does not matter how good the structure of the organisation is and how good the allocation of duties and responsibilities.

The importance of public authority staff to the efficiency and effectiveness of the organization providing public services cannot be overemphasized.

There is no doubt that as the role of the state changes and society improves, besides the importance of legality, efficiency, effectiveness and cost-efficiency. It is also more and more important how people (clients) are satisfied at the receiving side, and what is thought of services provided by the state.

This demand may be satisfied if the renewal, selection, employment, qualification and further education of the staff of organisation exercising public authority keep up with social demands.

After 1945, the closed system of civil service existing between the world wars was gradually replaced by an open system. The first consideration for job

${ }^{38}$ Zoltán Magyary, The rationalization of Hungarian public administration, Royal Hungarian University Press, Budapest, 1930, 167. 
applications was not professional knowledge but, political trustworthiness. There was no uniform public service code and the existence of such a code would not have been compatible with the political objectives. It is just natural that in a system like that, instead of the expectation and point of views of clients, satisfying slavishly the political will of the state enjoyed priority. The official procedure was quite authorial due in part the characteristics of the organization and staff. Since the 1960s and 1970s, economic and social change has strengthened legitimacy in public administration promoting the development of professionalism and legislation in this direction. ${ }^{39}$ From 1987, it was desirable to call for tenders, which meant an appreciation of professionalism..$^{40}$

After the transformation of the public administration took place, the first step in state employment policy was the adoption of Act XXIII of 1992, which set out a unified regulation concerning executives, officials and administrators of public administration organs. The Act aimed at establishing comprehensive regulations on an employment system in public administration, which facilitates unbiased, professional and legal official procedures. The following years saw several amendments trying to lighten the closed nature of the system.

From 2010, regulation was no longer uniform. the Act LVIII of 2010 has covered the employees of central and territorial state administration organs. The next step was Act CXCIX of 2011 on the status of public service officials, regulating the status of government officers and public service officials in a single code.

The reasons for adopting the Act on state officials (Act II of 2016) were to underline the duties performed by government offices and district offices, and the organisational and operational specificities of government offices. The act on state officials has been repealed by the Act on Government Administration (No. CXXV of 2018) which aims, among other things, to promote a more efficient governance system of government administration.

Having different regulations for public service officials not only creates the possibility for but help the executives and officials of state administration organs to comply with the requirements of lawfulness, effectiveness, cost-efficiency, as well as to the client-friendly and client-driven procedures in the course of fulfilling their duties.

For fulfilling these expectations, the best candidate and staff should be selected based on expectations. Continuous education and further education of public service officials not only broaden the professional basic knowledge they already have, but it may provide them with the possibility to leave their routines and acquire new knowledge, abilities and skills.

\footnotetext{
39 Árva et al: Public Administration Theory, 2nd edition, University Press, Debrecen, 2012, 193.

${ }^{40}$ György Gajduschek, Civil service. Personnel and Personnel system of Hungarian administration in the light of empirical data, Budapest, 2008, 176.
} 
Evaluating the performance of and qualifying those working in state administration covers the officials' communication with clients and examines as to whether they are polite and helpful with clients. The goal of the system of performance evaluation is that public service officials contribute to achieving the aim of their organisation by improving their competences (knowledge, education, skills, abilities, social roles, self-image, character traits, motivation); and this all leads to the satisfaction of those enjoying the services.

The establishment of the National University of Public Service created the organisational, institutional and personal conditions ${ }^{41}$ for a unified basic training of public servants. In the university's programmes of education and further education of wide range covers all the knowledge that provides a well-founded professional background and knowledge base for the implementation of a modern, $21^{\text {st }}$-century client-friendly public service practice.

\section{CLIENT CONSIDERATION OF ADMINISTRATIVE PROCEEDINGS}

The professional aspects of the allocation of public administration tasks and powers and the expectations of the clients are equal importance, since public authority activities must be organised and performed the same way as services are performed.

The complete achievement of the objective is dependent on the simultaneous satisfaction of more than one requirement, which is in particular:

- accessibility and simplicity,

- the unified organisation and fulfilment of duties,

- effectiveness (both fiduciary and technical aspects),

- being client-driven,

- integrated fulfilment of duties.

Accessibility means that the habits of people regarding administration and the venues visited by them for that purpose are taken into account. The proceedings concerning a given administrative case should not take the excessive length of time and costs, and that the office should be available without difficulty.

In terms of accessibility, it is important to determine basis levels and to determine the territorial competence of basic units. The most optimal level is dependent on the peculiarities of settlement patterns such as location, railways, public roads etc. The more habitat and smaller area a unit have the easier and cheaper for clients to have access to service points. ${ }^{42}$ Nonetheless, the fact geographical and

\footnotetext{
${ }^{41}$ Gábor Koltányi, "Carrier model in the service of public" Notary and Public Administration 3/2013, 5-7.

${ }^{42}$ Gábor Soós, Local Government institutionalization in Hungary, Academic Research, Frankfurt am Main, 2015, 31-75.
} 
settlement pattern specificities limit the number of alternatives and exclude the possibility of delineation based on similar features must not be forgotten.

A significant part of state administration cases cannot be dealt with at a basic level, first, due to lack of capacity in small settlements. Furthermore, certain special duties are so rare and yet are of high technical needs that they cannot be allocated to basic units. For reasons of economies of scale, these functions can be performed at a higher level, such as in counties, districts, etc.

From among client expectations regarding administrative services, an important expectation is the costs of administration covering more than one dimension. It includes the costs of contacting the authority, the costs of the procedure, the loss of income due to proceeding and other costs in the first place. General costs vary per sector; therefore, determining it is a complex methodological task.

The satisfaction of the general requirement for having administrative matters handled quickly and at an affordable cost may be an index for the use of official sources and the effectiveness of official procedures.

Social costs are dramatically reduced if the administration is available at a given place. The proceedings are client-friendly, competent and cooperative, if offices are open beyond working hours, and the accessibility and availability of administration venues improve.

Organising and performing duties in a unified manner may also contribute to the enforcement of client considerations. Especially in cases where there had been more authorities with different territorial competence and under the control of different organs, and thus any kind of proper cooperation, the cessation of unnecessary duplications and cost-efficiency was impossible.

Through integration, the quality difference between services can be reduced, central databases can be interconnected and the benefits of modern information technology can be exploited.

In addition, to weighting the pros and cons, customer considerations must be taken into account when defining state and local government tasks. The freedom of choice, in addition to professional considerations, has its limits imposed by the availability of budgetary sources and the arguments in favour and against maintaining and improving the system.

\section{THE IMPACT OF THE ORGANISATION, DUTIES AND STAFF ON STATE ADMINISTRATIVE PROCEDURES}

One of the classic, but often forgotten thesis of the science of public administration says that the organisation expresses and not determines the objectives.

The structure of state administration and administrative proceedings take on the bureaucratic form, based on German and Austrian models, in the second 
part of the $19^{\text {th }}$ century, in the course of a slow-paced development, because the non-professional, unexpected administration held by the nobility did not guarantee the coherent enforcement of the laws, public interest and rights.

In the period concerned, the modernisation of state administration and territorial administration came through the penetration of bureaucratic organisations in certain sectors of administration. The criteria of the specific organisation (competence and procedural norms, hierarchy, professionalism, qualification, etc.) were following and supporting the aspects of legality and lawfulness as the level of development of the state structure required so.

As rational and lawful administration covered more and more of the social conditions, official organs and the officials who were well-qualified most of the time and were operating such organs had more and more roles and became more and more important. Presumably, at this stage of development a professional, lawful, predictable solution to cases (without biases) is of greater value to people than a simple or quick solution to a procedure.

This starting position, even if changed a lot, remained of importance in the first part of $20^{\text {th }}$ century, even though this era saw several initiations for the modernisation of public administration, thus for the modernisation of administrative procedures.

After 1945, state administration was centralized and strictly bounded by politics.These conditions opened a new chapter for the social relations of specialised organs of the committee system. The organs of representation of counties being only formally autonomous and were autonomous only by name actually but a structure controlled from higher levels was behind. Thus, the people and client did not have a say as to how specialised administration organs should work, partly due to the redistributive operation of the state. For example, a rather lengthy and bureaucratic proceeding and redistribution was a daily practice of the housing authority. Logically, client considerations in official procedures were expressed mainly in ideological and political programmes and propaganda publications.

After 1990, the system of organs that are disintegrated, for reasons explained above but growing in number and the sectoral ministries were rather interested in maintaining the status quo rather than giving larger attention to client considerations. This strong resistance is underpinned by the partial success and failure of modernisation and rationalisation programs between 1990 and 2010.

After 2010, the integration of territorial bodies was characterized not only by economy but also by efficiency, as the quality of public services in the $21^{\text {st }}$ century is a determinant of competitiveness. Concentrating the organisation, sources and professional staff express the objective that the new order of state administration services should attempt to satisfy, besides the expectations of the social and economic environment, client consideration as well. 
The organisational system of the government offices, consisting of the government offices of the capital city, government offices of counties, the district offices, official branches as well as the officials working in settlements and providing support to the work of all these organs follows the logic of integration and economy. The scale of changes was facilitated by the revolutionary expansion of information technology and the development of the system of one-stop shops.

These steps cannot achieve much if they are not followed by the modernisation of the rules of the administrative procedures, the improvement of the laws and the introduction of new legal institutions, which consider client considerations of equal importance.

The organisation is only a structure, of course. The structure becomes an institution only if those working in it establish, adopt and incorporate into their daily routine the fundamental values, norms, procedures, practices and habits that later on become written and unwritten rules. Namely, when they create an organisational culture. The key role in this process is the officials who, in addition to the objective conditions of operation, ultimately determine the image of the official procedure.

\section{Instead of conclusion}

Despite the modernisation that requires significant resources and change of attitude, the system of public administration issues can be further developed. In 2010 a new process was launched which brought fundamental changes to the Hungarian public administration. The tendency is strong centralization, the integration of organizations and tasks, focusing on economy and efficiency. The accelerated legislation and the new direction of staff policy Magyary program, ${ }^{43}$ career model and professional ethics also serve these purposes.

The integrated governmental office model requires management methods that ensure consistent practice in the administration of public matters. The real danger is that with the increase of concentration the possibility of acquiring and controlling local processes decreases, so the decisions made by specific local interests and needs may differ from the national direction.

Customer's administrative habits are determined by several factors: location, age, income, travel options etc. Based on these factors, it is clear that spatial mobility is no problem for educated social groups in a better financial position.

The case management system only helps, but essentially not change the handling of the official affairs of the older population living mainly in small settlements. Besides, in the time of large-scale rapid changes there is usually less chance for feedback, collection, analyses and processing patches. This can lead to a democratic deficit and may hinder the necessary adjustments. It is not disputed, that cases are

${ }^{43}$ Magyary Zoltán Public Administration Development Program (MP 11.0.) Ministry of Public Administration and Justice, Budapest, 10 June, 2011. 
ultimately settled in the local office during day-to-day administration. This aspect of reforms also deserves attention from strengthening confidence in governance and public administration.

\section{REFERENCES}

Almássy, Gy., Development of Public Administration and Technology, PhD Thesis, Budapest, 2012, 55.

Árva, Zs., Balázs, I., Barta, A., and Veszprémi, B., Public Administration Theory, 2nd Edition, Debrecen: University Press, 2012, 93.

Balázs, I., Changes in Public Administration in Hungary and Europe form the Change of Regime to the Present Day, Debrecen: University Press, 2011, 59.

Balázs, I., 'Alternatives of Organising State Services by Administrative Authorities' 2015, New Hungarian Public Administration, vol, 8, no. 3, 2-13.

Barta, A., Territorial State Administration in Hungary, Budapest: Gondolat, 2013, 133-136.

Barta, A. 'Changes of Territorial State Administration 2010-2014' 2014, New Hungarian Public Administration, vol.7, no. 4, 1-8.

Barta, A., 'Integration Processes for Territorial Administration in 2015', New Hungarian Public Administration, vol. 8, no. 3, 14-20.

Berényi, S., Szamel, L., Baracka, R., and Ivancsics I., Hungarian State Administration Law. General Chapter, Budapest: Ministry of Home Affairs, 1984, 138-153.

Boros, A., 'The Third Generation of the Hungarian Administrative Procedural Law is Ákr. (I)' 2018, New Hungarian Public Administration, vol. 11, no. 1, 1-8.

Csizmadia, A., Bureaucracy and Administrative Reforms in Hungary, Budapest: Gondolat, 1979, 8-9.

Demmke, C., 'Governmental, Organisational and Individual Performance', 2006, Eipascope, vol. 5, no. 1, 5-12.

Dudas, F., 'Effective Information, Improving through e-public administration, the level of information provided to clients, with special regard to call centres' 2004a, Notary and Public Administration, vol. 6, no. 3, 12.

Dudas, F., 'Administrative Customer Support Charter', 2004b, Notary and Public Administration, vol, 6, no. 4, 6-7.

Dudas, F., Improvement of Administrative Service System in the Light of a Survey' 2004c Notary and Public Administration, vol. 6, no. 5, 11-15.

Dudas, F., 'On Improving the Performance of the Public Administration'2006, Notary and Public Administration, vol. 8, no.3, 0-11.

Fonyó, Gy., Handbook of Local Councillors, Budapest: MTTH, 1985, 25-61.

Gajduschek, Gy., Civil Service. Personnel and Personnel System of Hungarian Administration in the Light of Empirical Data, Budapest, 2008, 176.

General Administrative Order, Akr. 2016-Ket. 2014, (ed.) Juhász, Z., Budapest, Wolters Kluwer, 2017, 223-227.

Hajas, B., et al, Rules of Administrative Procedure I. Explanation of General Administrative Order, (ed.) Petrik, F., Budapest: HVG ORAC, 2017, 27-28. 
Imre, S., 'The Influence of Offices on the Public', in Martonffy (ed.), Hungarian Public Administration Nowadays, The Path of Modern Public Service 2,. Lectures of the 1936 Continuing Education Course, Hungarian Royal State Publisher, 1936, 27-44.

Kasza, M., Mezey, L., Mitták, T., 'Three Blows to the Clerks' I-II. 2015, Notary and Public Administration, vol.17, no. 5. 16-24.

Kilényi, G., Commentary on the Administrative Procedure Act, Budapest: Complex Wolters, 2009, 23-33.

Kiss P., 'De-Government and /or Municipal Empowerment in the Village? How to Continue Local Administration? Questions of the Division of Powers between District and Local Authorities.' 2015, Notary and Public Administration, vol. 17, Special issue, 5-7.

Koltányi, G., 'Carrier Model in the Serve of the Public' 2013, Notary and Public Administration, vol. 15, no. 3, 5-7.

Lörincz, L., Basic Institution of Public Administration, Budapest: HVG ORAC, 2010, $172-175$.

Magyary, Z., The Rationalisation of Hungarian Public Administration, Budapest: Royal Hungarian University Press, 1930, 167.

Magyary, Z., Hungarian Public Administration, Budapest: Royal Hungarian University Press, 1942.

Magyary Zoltán Public Administration Development Program (MP 11.0) Ministry for Public Administration and Justice, Budapest, 10 June 2011.

Martonffy, K., The Renewal of Hungarian Public Administration, Royal Hungarian University Press, 1940.

Pálné Kovács, I., 'Difficulties in Reforming the Middle Level' 2006, Hungarian Public Administration, vol. 56, no. 3-4, 228.

Pilz, T., 'Organization and Operation of the CaÍpital Offices and County Government Offices' AROP-1.1.26-2013-0001 Training of Government Office Staff, Manuscript, 24-25.

Soós, G., Local Government Institutionalization in Hungary, Frankfurt am Main, Academic Research: 2015, 31-75.

Szabó, L., 'The Goal is to Serve Customer Better' 2004, Notary and Public Administration, vol.6, no. 2, 20.

Szabó, L., 'New Law to Serve Customers' 2005, Notary and Public Administration, vol. 7, no. 1, 6-7.

Szekeres, A., 'Changes in the Notary's Administrative Powers' 2012, Notary and Public Administration, vol. 15, no. 3, 5-7.

Toth, Z., 'Characteristics of Service State in the Administrative Procedures Act' 2005, Notary and Public Administration, vol. 7, no. 2, 5-7.

Zöld Nagy, V., 'Districts and Formation of Districts Offices', 2012, Notary and Public Administration, vol. 14, no. 3, 4-5.

Legal Resources:

Act IV of 1957 on General Rules of Administrative Procedure

Act IV of 1957 as amended by the Act of 1981 Law

Act XXIII of 1992 on the Status of Civil Servants 
Government decree No.1113/2003. (XI. 11.) Korm. on the Modernization of Administrative Services

Act of CXL of 2004 on General Rules of Administrative Proceedings and Services

Government decree No 1191/2010. (IX.14.) Korm. on the Transformation of the Territorial Administration

Act LVIII of 2010 on the Status of Government Officials

Act CXCIX of 2011 on Civil Servants

Act CLXXXVI of 2015 on Changes to the Law Related to the Reduction of Administrative Bureaucracy

2016/123 EC Directive on Market Services

Act CL of 2016 on General Public Administration Procedures

Act LII of 2016 on State Officials

Government Decree No. 86/2019 (IV. 23.) Korm. on Capital, County Gover Offices and District (district capital) Offices

Act CXXVof 2018 on Government Administration

Internet resources:

http://www.kormany.hu/download/8/42/40000/Közigazgatás_fejlesztesi_stratégia_pdf accessed on 2nd September 2018. 
Др Золииан 3. Јожа, ванреgни иррофесор

Универзитетети у Сеіедину

Правни факулитети

jozsaz545@gmail.com

\section{Основни кораци у развоју јавне управе у Мађарској}

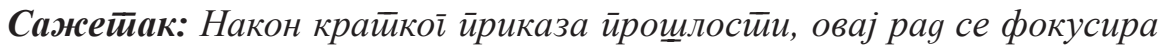

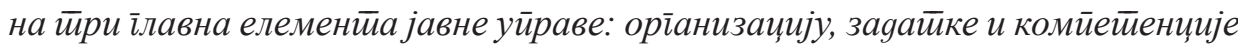

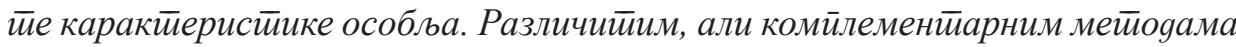
истираживања (иситоријским, уйоредним и gоимайским) ириказујем иромену у уйрављағу и раяу државне уйраве йоком йојеgиних истиоријских иериояа ие разлоїе који су gо т̄оїа довели.

Некаяашња формализована, на суборуинацији заснована ауминистираиија йосиетеиено је устиуйила местио јавној уирави која је данас йостиала ори-

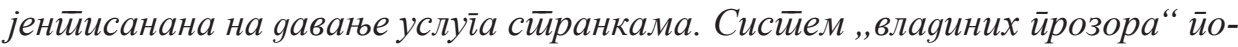

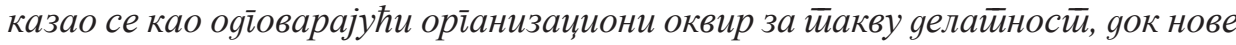

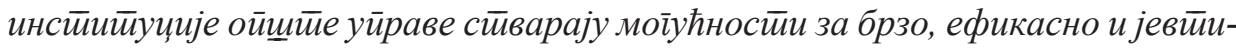
но давање услуїа.

Посвећености, образованости и иррофесионализам зайослених у јавној уйра-

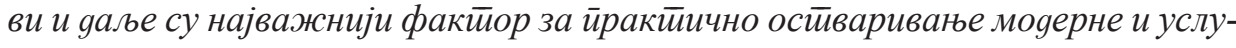
жне државе оријенииисане на услуіе. Промена каракиеера државне уйраве

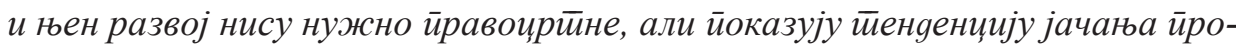

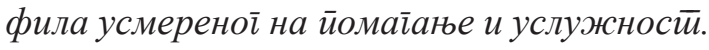

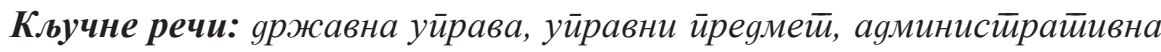

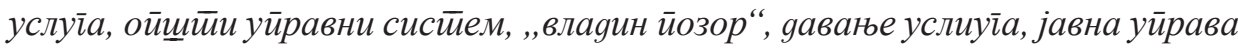
склона сииранкама.

Датум пријема рада: 24.04.2020. 